\title{
A review of droughts on the African continent: a geospatial and long-term perspective
}

\author{
I. Masih ${ }^{1}$, S. Maskey ${ }^{1}$, F. E. F. Mussá ${ }^{1,2}$, and P. Trambauer ${ }^{1}$ \\ ${ }^{1}$ UNESCO-IHE, Institute for Water Education, P.O. Box 3015, 2601 DA Delft, the Netherlands \\ ${ }^{2}$ Eduardo Mondlane University, Faculty of Engineering, Av. de Moçambique km 1.5, C. Postal 257, Maputo, Mozambique \\ Correspondence to: I. Masih (i.masih@unesco-ihe.org)
}

Received: 31 January 2014 - Published in Hydrol. Earth Syst. Sci. Discuss.: 6 March 2014

Revised: 14 August 2014 - Accepted: 14 August 2014 - Published: 17 September 2014

\begin{abstract}
This paper presents a comprehensive review and analysis of the available literature and information on droughts to build a continental, regional and country level perspective on geospatial and temporal variation of droughts in Africa. The study is based on the review and analysis of droughts occurred during 1900-2013, as well as evidence available from past centuries based on studies on the lake sediment analysis, tree-ring chronologies and written and oral histories and future predictions from the global climate change models. Most of the studies based on instrumental records indicate that droughts have become more frequent, intense and widespread during the last 50 years. The extreme droughts of 1972-1973, 1983-1984 and 1991-1992 were continental in nature and stand unique in the available records. Additionally, many severe and prolonged droughts were recorded in the recent past such as the 1999-2002 drought in northwest Africa, 1970s and 1980s droughts in western Africa (Sahel), 2010-2011 drought in eastern Africa (Horn of Africa) and 2001-2003 drought in southern and southeastern Africa, to name a few. The available (though limited) evidence before the 20th century confirms the occurrence of several extreme and multi-year droughts during each century, with the most prolonged and intense droughts that occurred in Sahel and equatorial eastern Africa. The complex and highly variant nature of many physical mechanisms such as El Niño-Southern Oscillation (ENSO), sea surface temperature (SST) and land-atmosphere feedback adds to the daunting challenge of drought monitoring and forecasting. The future predictions of droughts based on global climate models indicate increased droughts and aridity at the continental scale but large differences exist due to model limita-
\end{abstract}

tions and complexity of the processes especially for Sahel and northern Africa.

However, the available evidence from the past clearly shows that the African continent is likely to face extreme and widespread droughts in future. This evident challenge is likely to aggravate due to slow progress in drought risk management, increased population and demand for water and degradation of land and environment. Thus, there is a clear need for increased and integrated efforts in drought mitigation to reduce the negative impacts of droughts anticipated in the future.

\section{Introduction}

Drought is a recurrent climatic phenomenon across the world. It affects humanity in a number of ways such as causing loss of life, crop failures, food shortages which may lead to famine in many regions, malnutrition, health issues and mass migration. It also causes huge damage to the environment and is regarded as a major cause of land degradation, aridity and desertification. The impacts of droughts are witnessed at a range of geographical scales. For instance, individual families or communities may lose their livelihoods and source of water, subject to acute food shortages and health issues and the country's economy may be severely impacted. The available estimates on drought impacts suggest that, during the period 1900-2013, there were 642 drought events reported across the world resulting in a huge toll to humanity, killing about 12 million people and affecting over 2 billion (EM-DAT, 2014). The total economic damages are estimated at USD 135 billion (Table 1). 
Table 1. Overview of a number of droughts and their impact across the world during 1900-2013.

\begin{tabular}{|c|c|c|c|c|}
\hline Continent & $\begin{array}{r}\text { \# of } \\
\text { events }\end{array}$ & $\begin{array}{r}\text { \# of } \\
\text { people killed }\end{array}$ & $\begin{array}{r}\text { \# of } \\
\text { people affected }\end{array}$ & $\begin{array}{r}\text { Damage } \\
\left(\times 10^{3} \text { USD }\right)\end{array}$ \\
\hline Africa & 291 & 847143 & 362225799 & 2920593 \\
\hline Americas & 134 & 77 & 69505391 & 50471139 \\
\hline Asia & 153 & 9663389 & 1707836029 & 44251865 \\
\hline Europe & 42 & 1200002 & 15488769 & 25481309 \\
\hline Oceania & 22 & 660 & 8034019 & 12303000 \\
\hline Total & 642 & 11711271 & 2163090007 & 135427906 \\
\hline
\end{tabular}

Drought remains a major disaster causing huge damages to humanity, the environment and the economy, despite making considerable progress on monitoring, forecasting and mitigation of droughts across the world. The lack of desired level of success could be attributed to many reasons. Drought is a complex phenomenon, which varies every time in terms of its onset, intensity, duration and geographical coverage. The capacity of people facing this hazard may be limited to avoid adverse impacts compounded by shortcomings in government capacity (e.g. financial, institutional and political) to provide short-term relieve and install long-term drought mitigation measures. There is an urgent and dire need to progress on various fronts of drought mitigation such as early warning and forecasting, building the resilience of the societies, shortterm relief efforts, long-term planning and capacity building (e.g. Calow et al., 2010; Clarke et al., 2012; Dondero, 1985; Falkenmark and Rockström, 2008; GFDRR, 2011; IFAD, 2010, 2011a, b; Logar and van den Bergh, 2013; Mishra and Singh, 2010; Msangi, 2004; Sehmi and Kundzewicz, 1997; Tadesse et al., 2008; Tøttrup et al., 2012; UNISDR, 2004, 2010; Vicento-Serrano et al., 2012; Vogel et al., 2010; World Bank and GFDRR, 2010).

Understanding gained from detailed analysis of historic drought events offers enormous possibilities to carry out better drought management planning and to mitigate impacts of droughts (Vicente-Serrano et al., 2012). A sound sciencebased geospatial analysis of the past drought events and their causes can facilitate the improvement of drought mitigation and preparedness plans. This can also help with determining the spatial and temporal variability of drought hazard and the vulnerability of water resources, vegetation systems and society to drought. The analysis of historical droughts can provide information on deficits in water demand and likely impacts on water resources and environment, which is essential for drought risk reduction, planning new projects and reviewing the existing ones. Such studies can also provide necessary information on the periodic nature of droughts and their relationship with increasing water demand or climate change (Mishra and Singh, 2010). Moreover, the outlook of the current and future drought events in the historic context could facilitate in applying low-risk and long-term plans to use, conserve and sustain water and other natural resources (Touchan et al., 2008). The current efforts by the scientific community in this direction are very limited and require further attention (Mishra and Singh, 2010; Touchan et al., 2008; Vicente-Serrano et al., 2012; Vogel et al., 2010). The available scientific studies do not provide enough geospatial and long-term temporal coverage of past drought events at global and continental levels. However, the increasing number of available studies offers great opportunity to conduct such an analysis. The major focus of this paper is to review the available literature in the context of Africa where impacts of droughts are more severe and result in significant loss of life, negative effects on people and damages to the economy and environment. Most countries in Africa also lack the necessary capacity and resources to make required progress to address this catastrophic hazard (e.g. GFDRR, 2011; Tadesse et al., 2008; Vogel et al., 2010).

A recent global review on droughts and aridity by Dai (2011) indicated that large-scale droughts have frequently occurred during the past 1000 years across the globe. This review briefly reported a few of these severe and multiyear droughts in North America, China and Africa, but does not provide the detailed review of the historic droughts across the world. For Africa, the focus was on the severe, widespread and prolonged droughts that occurred during 1970s and 1980s in western Africa (Sahel region). The study mainly focused on aridity changes from 1950 to 2008 and provided foresight for the 21 st century. One of the important conclusions of this paper is that the global aridity and drought areas have increased substantially during the 20th century and attributed to widespread drying since 1970s over Africa, southern Europe, East and South Asia, eastern Australia and many parts of the northern mid-high latitudes. The aridity trends are projected to continuously increase in the 21 st century. However, the study of Sheffield et al. (2012) shows that drought patterns have been increasing over last 60 years, though not as alarming as usually projected. Mishra and Singh (2010) conducted a comprehensive review on drought concepts and a critical evaluation of the most widely used indicators for drought assessment. But the review remains limited in terms of description of the historic droughts and only briefly mentions few of them with their main impacts. For Africa, the study only enlisted the severe droughts in Sahel that occurred during 1910s, 1940s, 1960s, 1970s and 1980s. These droughts caused huge socio-economic and environmental impacts in this semi-arid region resulting in massive-scale migration, famine and environmental degradation (desertification), especially during the last two drought episodes. The study noted that growing demand for water, limited sources of water and changes in spatio-temporal patterns of climate are aggravating the drought impacts in the world.

There are a growing number of studies addressing various drought related issues for Africa. Most of these studies 
focused on a specific region, i.e. southern Africa (e.g. Clarke et al., 2012; Cornforth, 2013; Dube and Jury, 2000, 2002, 2003; Green, 1993; Jager et al., 1998; Manatsa et al., 2008; O'Meagher et al., 1998; Richard et al., 2001; Unganai and Kogan, 1998; Vogel et al., 2010), Sahel (western Africa) (e.g. Giannini et al., 2008; Govaerts and Lattanzio, 2008; Kasei et al., 2010; Lebel et al., 2009; Lodoun et al., 2013; Traore and Fontane, 2007; Zeng, 2003), eastern Africa (Horn of Africa) (e.g. Anderson et al., 2012; Dutra et al., 2013; Syroka and Nucifora, 2010) and northwestern Africa (e.g. Touchan et al., 2008, 2011). There are few studies which attempt to cover more than one region (e.g. Calow et al., 2010; Herweijer and Seager, 2008; Rojas et al., 2011; Naumann et al., 2012; Tadesse et al., 2008; Verschuren, 2004). These and many other studies are comprehensively reviewed and discussed in the following sections. Most of them investigate one or more drought related subjects i.e. the study of a specific drought event or historic droughts in a country or regional perspective, methodological developments on drought indicators, causes of droughts, forecasting and early warning systems, impact analysis and drought risk reduction, drought planning and management and capacity building. None of them provide a long-term analysis of droughts considering past, present and future perspective at the continental scale.

There are a growing number of continental and global data sets on drought. For instance, there are specific continental drought monitoring and forecasting systems that deal with specific drought related information in real time as well as historical data. The examples are the African drought monitor: http://hydrology.princeton.edu/adm (Sheffield et al., 2013) and the DEWFORA African drought observatory: http: edo.jrc.ec.europa.eu/dewfora/ (Barbosa et al., 2013). Moreover, the EM-DAT database (http://www.emdat.be/ database) provides information on historic droughts recorded across the world along with their impacts. Significant advances have been made on the global-scale estimation of various drought-related indicators (e.g. standardized precipitation and evaporation index, SPEI) (Vicento-Serrano et al., 2012). Several remote-sensing-based data and products have been developed over time (e.g. Rojas et al., 2011; Sheffield et al., 2013). These efforts have resulted in significant increase in the scientific literature and databases, which can facilitate continental-scale analysis of droughts in terms of severity, spatial and temporal coverage.

The main objective of this study is to review available information and literature and conduct a detailed geospatial and long-term analysis of droughts across the African continent. We examine the major causes of droughts reported in the literature and present findings and important discourses on drought trends (including frequency, intensity and geospatial coverage), temporal variability, desiccation (aridity) and causes of drought.

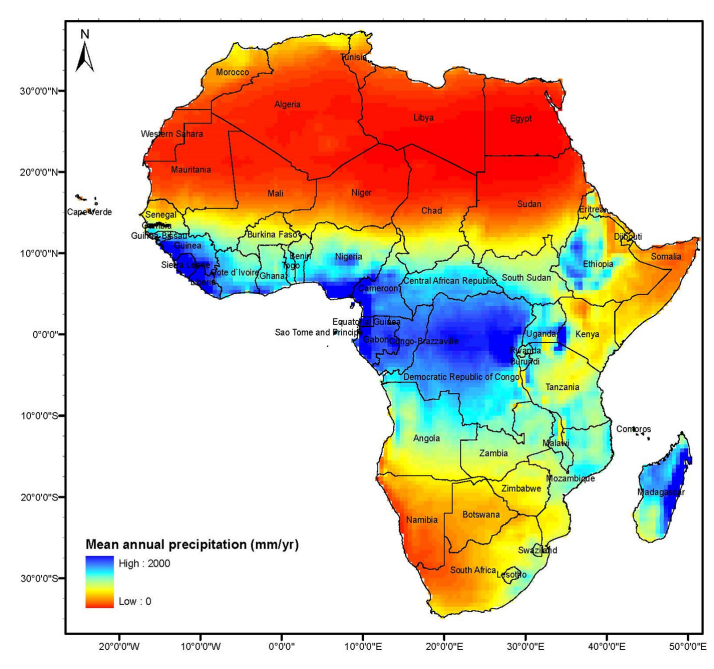

Figure 1. Map of the African continent with country names and rainfall patterns. (Data source: ERA-Interim corrected with GPCP v2.1; period: 1979-2010. See Trambauer et al. (2014) for detailed explanation).

\section{Materials and methods}

\subsection{Study area}

This study focuses on the entire African continent. However, analysis and discussion is also presented in the regional and country perspectives. It is important to note the differences in grouping various countries in different regions. For instance, EM-DAT groups African countries into northern, middle, southern, eastern and western Africa). On the other hand, many regional studies are focused on Sahel (includes countries in western Africa between Sahara desert and Guinea coast rainforest, about 18 to $15^{\circ} \mathrm{N}$ ), Horn of Africa (Ethiopia, Somalia, Kenya), equatorial eastern Africa and southern Africa. The special reference to countries in a given region is made wherever deemed necessary. In this study, the continent is grouped into northern, western (Sahel), eastern, middle and southern Africa (Table 2).

The rainfall depicts very high spatial and temporal variability across the African continent (Fig. 1). Northern Africa receives very low rainfall and has a desert climate. The highest rainfall occurs in middle African countries and some countries along with west coast of West Africa. These countries have (sub)-humid climatic characteristics. The highest spatial and temporal variability of rainfall is found across most of the countries having a semi-arid climate within western, eastern and southern Africa. Variations within a country are also important to note, for instance, the eastern part of Ethiopia receives much less rainfall (semi-arid) compared to the Ethiopian Highlands (sub-humid) in the western part. There are distinct differences in intra-annual variability across the regions. Southern Africa receives most of the rainfall during October-March, whereas Sahel rainfall is 

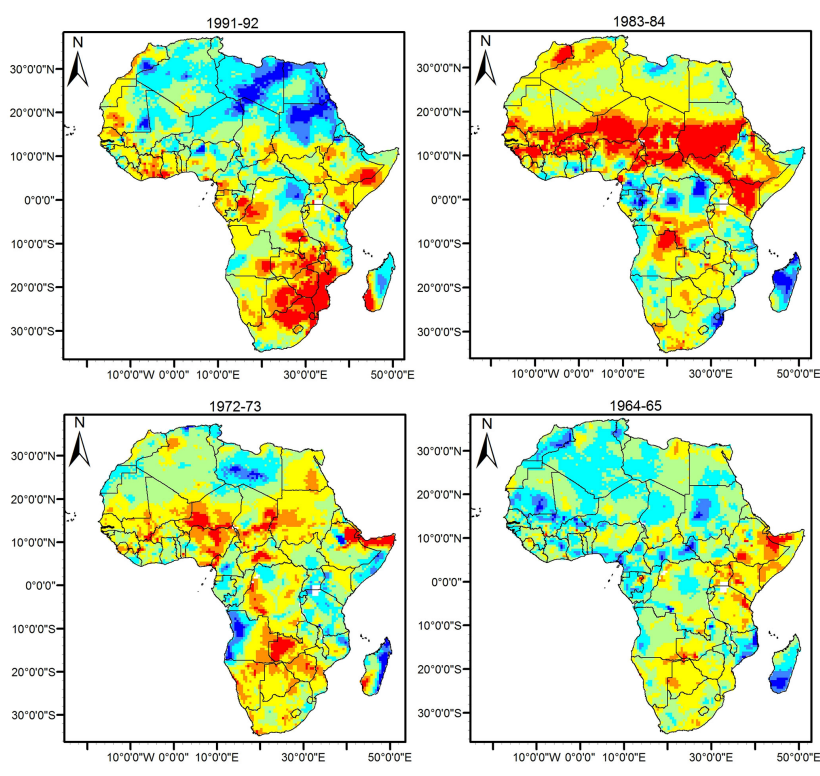

Drought classification

Extremely dry (SPEI <-2.0) $\square$ Near normal $(-0.5<$ SPEI $<0.5)$

Severely dry $(-2.0<\mathrm{SPEI}<-1.5) \quad$ Moderately wet $(0.5<\mathrm{SPEI}<1.5)$

Figure 2. Geospatial coverage of extreme droughts of 1964-1965, 1972-1973, 1983-1984 and 1991-1992 indicated by 12 months SPEI (October to September). (Data source: global SPEI database available at http://sac.csic.es/spei/database.html, version 2.2 retrieved in January 2014.)

concentrated during July-August summer monsoon period. Most countries in the Horn of Africa and equatorial eastern Africa receive rainfall in two seasons: October-December (short rainfall season) and March-May (long rainfall season). Northwestern Africa receives most of the rainfall during October-April.

\subsection{Data and methods}

The main data and information sources for this study are collected from the literature (e.g. published, peer and nonpeer reviewed, unpublished sources). More than 100 literature sources were studied in detail, after initially skimming over 500 articles searched from relevant international journals (individual journals and search engines), African journals, donor reports and other sources. The list of reviewed material is not exhaustive, though an effort has been made to conduct compressive coverage.

The global data set on droughts from EM-DAT website (http://www.emdat.be/database) were accumulated for the available period 1900-2013. This data set provides country/regional/continental level estimates on drought events, people killed and affected and economic damage. Additionally, a global database on SPEI was used to analyse droughts with the aim to substantiate the findings of this review (http: //sac.csic.es/spei/home.html). It is acknowledged that a number of drought indicators are available, each with its own
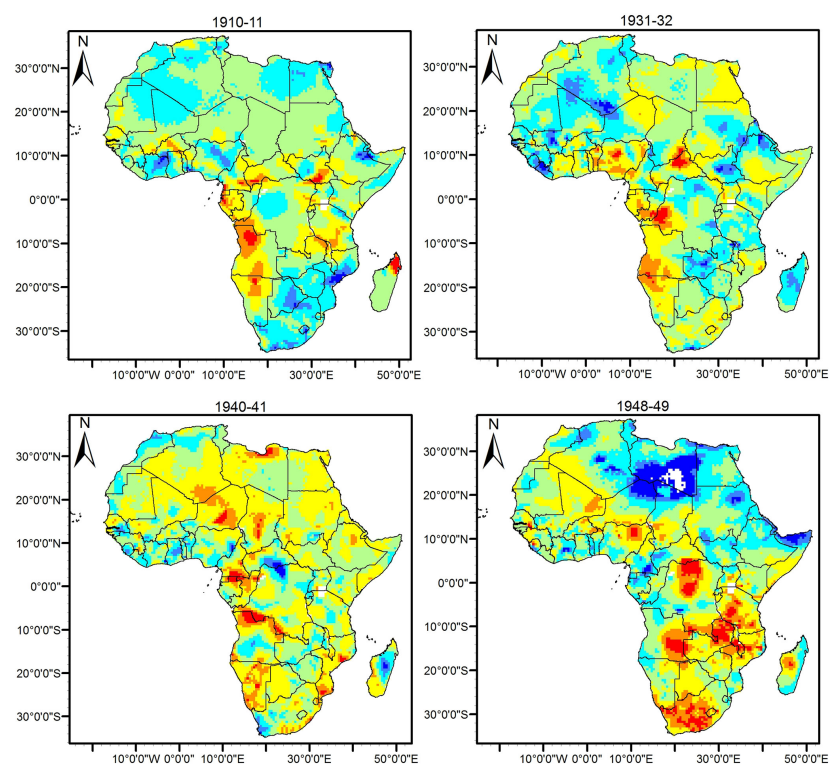

Drought classification:

Extremely dry (SPEI <-2.0)

Exremely dry (SPE| <-2.0) $\square$ Near normal $(-0.5<$ SPEI $<0.5)$

Severely dy $(2.0<\mathrm{SPE}<-1.5) \quad$ Moderately wet $(0.5<\mathrm{SPEI}<1.5)$

Figure 3. Geospatial coverage of selected droughts 1910-1911, 1931-1932, 1940-1941 and 1948-1949 indicated by 12 months SPEI (October to September). (Data source: global SPEI database available at http://sac.csic.es/spei/database.html, version 2.2 retrieved in Jan 2014.)

strengths and weaknesses (e.g. Mishra and Singh, 2010; Dai, 2011; Zargar et al., 2013). For example, the decile index (Gibbs and Maher, 1967) is easy to compute; however, it requires a long time series of data to have accurate results. With the Palmer Drought Severity Index (PDSI) (Palmer, 1968), abnormality of agricultural droughts can be identified and it also shows historical aspects of current conditions. The disadvantage of this method is that it depends on soil moisture data and its properties which are often very difficult to assess, especially at a larger spatial scale and in spatially distributed manner. The widely used standardized precipitation index (Mckee et al., 1993; Zargar et al., 2011) seems to have advantages because it is a simple method that requires few data (only precipitation) for its computation. The SPEI is a widely used drought indicator which uses precipitation and potential evapotranspiration for its computation. It has the ability to monitor onset, intensity and duration of drought. The indicator is very suitable to study geospatial and temporal variation of drought including the impact of global warming. This indicator is primarily related to meteorological drought and does not offer as such estimates on agricultural, hydrological and socio-economic aspects of droughts, though it could be seen as a proxy to these droughts as eventually they are caused by the deficit in precipitation. The detail discussion on various drought indicators and their comparative basic concepts and various perceptions on drought can be found in the 
literature (e.g. Dai, 2011; Mishra and Sing, 2010; Ntale and Gan, 2003; Smakhtin and Schipper, 2008; UNISDR, 2004; Zargar et al., 2011).

\section{Results and discussion}

\subsection{Geospatial and temporal pattern of droughts during 1900-2013}

The summary of the selected literature reviewed is presented in Table 2, indicating drought years, geographical location and key relevant findings. While preparing this Table, an effort was made to avoid duplication of similar studies and yet provide geospatial and temporal coverage. Another important consideration was to examine important discourses most relevant to the topic of this paper. There are a rapidly growing number of studies on various drought related issues, especially during the last decade. The available studies cover most parts of Africa, though coverage is low for middle Africa which is understandable as in this region climate is humid and droughts are not as catastrophic as in the other regions. Meteorological drought remains the main subject of most studies followed by agricultural drought. Studies examining hydrological droughts and the impacts of human uses of water on the assessment and intensification of these droughts are limited.

Table 3 provides a summary of the drought events recorded in the EM-DAT database along with the number of people killed and affected and estimated economic damage. This widely used database provides very useful information for this study. However, caution is required while using it for a specific purpose due to several reasons. First, the available information underestimates the total number of drought events per country and consequent impacts. Generally, a much lower number of droughts are recorded for many countries (e.g. Morocco, Tunisia, Algeria, Sudan, Zimbabwe and South Africa) for the period 1900-2013, which prohibits formulating a century-scale picture of drought patterns for these countries. The information before 1960s is not available for most of the countries. Similarly, no information is available for many recorded drought events on the number of people killed and affected and economic damage. Thus, aggregated values of these indicators, which are often used, give much lower estimates of drought effects. Second, in the aggregation of the number of events, the method used by EM-DAT and many users takes a country level perspective. In this way, a drought event occurred during one year in many countries in a region is counted more than once. This should be properly examined, especially when studying the region with similar climatic regimes. In the scientific literature, regional and multi-year droughts are often referred as one drought event (Table 2). This difference limits a straightforward comparison of the droughts given in Tables 2 and 3 .

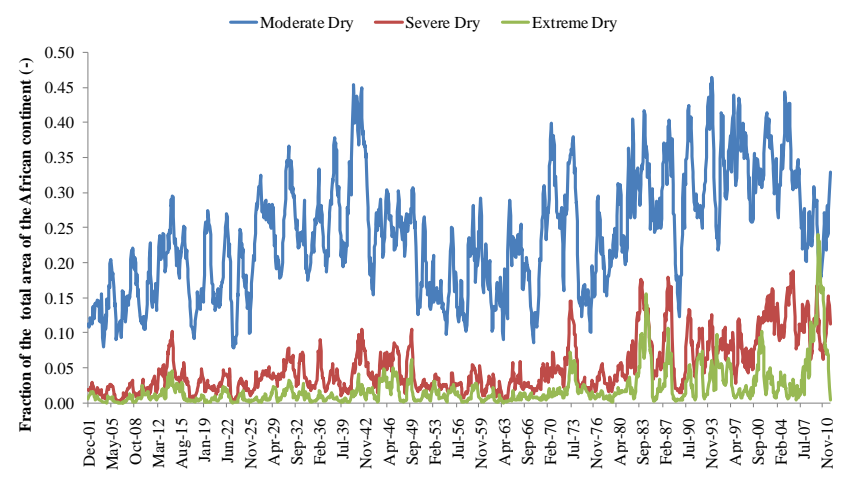

Figure 4. Fraction of the African continent under different drought conditions computed from the 12 month SPEI data set. (Data source: global SPEI database available at: http://sac.csic.es/spei/ database.html, version 2.2 retrieved in May 2014). Note: moderate dry $(-1.5<$ SPEI $<-0.5)$; severe dry $(-2.0<$ SPEI $<-1.5)$; extreme dry (SPEI $<-2.0)$.

A number of inferences are drawn from the analysis of the available data and scientific evidence reviewed in this paper (Tables 2 and 3). The frequency, intensity and geospatial coverage of droughts have significantly increased across the entire African continent during the second half of the 1900-2013 period. This inference is supported by studies conducted at continental scale (e.g. Dai, 2011, 2013) as well as by most of the regional and country level studies (e.g. Ouassou et al., 2007; Touchan et al., 2008, 2011, Elagib and Elhang, 2008; Kasei et al., 2010; Manatsa et al., 2008; Richard et al., 2001). The available data (though limited in temporal coverage) from EM-DAT also supports this observation (Table 2).

This point is further substantiated by Figs. 2, 3 and 4. The drought shown in Figs. 2 and 3 were reported by most of the reviewed literature and thus were chosen for the illustration. Figure 2 shows the geospatial coverage of the four most extreme droughts which occurred during past 50 years. Three out of these four droughts (1972-1973, 1983-1984 and 1991-1992) were most severe and could be regarded continental in nature as they spanned over many sub-regions and covered wide areas of the African continent; none of the previous droughts during 20th century were as wide spread and intense in comparison to these (Fig. 3). Figure 4 shows the area of the African content under different drought categories based on SPEI data analysis conducted in this study. On this data, the widely used non-parametric Spearman Rank test (e.g. Masih et al., 2011) was applied to test the statistical significance of the trends. The results revealed a statistically significant increase (at $99 \%$ significance level) in the area under all categories of drought (e.g. moderate, severe and extreme droughts) for the African continent during 1901-2011. Figure 4 exhibits these findings and the visual inspection also indicates the increasing trend in the geospatial extent of the African continent under drought. 
Table 2. Summary of the selected literature reviewed in this study.

\begin{tabular}{|c|c|c|}
\hline Reference & $\begin{array}{l}\text { Drought enlisted by region/country/basin during } 1900 \\
\text { to } 2013\end{array}$ & Remarks \\
\hline \multicolumn{3}{|l|}{ Northern Africa } \\
\hline Ouassou et al. (2007) & $\begin{array}{l}\text { Morocco: } 1904-1905,1917-1920,1930-1935,1944- \\
\text { 1945, 1948-1950, 1960-1961, 1974-1975, 1981-1984, } \\
\text { 1986-1987, 1991-1993, 1994-1995, 1999-2003 }\end{array}$ & $\begin{array}{l}\text { The study shows that droughts of } 1944-1945,1982-1983,1994-1995 \text { and } 1999-2000 \text { were } \\
\text { the driest agricultural seasons. Most severe hydrological droughts were } 1980-1981,1985-1986 \text {, } \\
1991-1992,2000-2001,2002-2003 \text {. This study describes the institutional change in drought man- } \\
\text { agement in Morocco with progress, though slow, from crisis management to more risk manage- } \\
\text { ment. }\end{array}$ \\
\hline Touchan et al. (2011) & $\begin{array}{l}\text { Northern Africa - Morocco, Algeria and Tunisia: } 1945- \\
\text { 1946, 1981-1982, 1999-2000 }\end{array}$ & $\begin{array}{l}\text { The study uses tree-ring chronologies to investigate climate of northern Africa and have con- } \\
\text { structed Palmer Drought Severity Index (PDSI) for Morocco, Algeria and Tunisia back to } \\
\text { AD } 1179 \text {. The later half of the 20th century emerged as the driest among last nine centuries. }\end{array}$ \\
\hline Touchan et al. (2008) & $\begin{array}{l}\text { Northwestern Africa - Algeria and Tunisia: 1920s, } \\
\text { 1940s, 1945, 1999-2002 }\end{array}$ & $\begin{array}{l}\text { The study uses tree-ring chronologies to investigate climate of northern Africa and has constructed } \\
\text { PDSI for Algeria and Tunisia for the period AD 1456-2002. The study mentions } 19 \text { droughts } \\
\text { occurred during 20th century compared to } 12-16 \text { droughts per century during earlier periods. } \\
\text { However, specific years or decades in which they occur are not given. The multi-year drought of } \\
1999-2002 \text { is the most severe in the last five centuries. }\end{array}$ \\
\hline Elagib and Elhang (2011) & $\begin{array}{l}\text { Sudan: 1969-1970, 1972-1973, 1979-1985, 1990- } \\
\text { 1991, 2002-2008 }\end{array}$ & $\begin{array}{l}\text { The study examines the drought episodes in Sudan using PDI drought index estimated from rain- } \\
\text { fall and temperature of } 14 \text { stations across Sudan for the period 1940s to } 2008 \text {. The study shows } \\
\text { several multi-year droughts after 1970s and suggested intensifying drought evidence. El Niño is a } \\
\text { major driver of droughts in Sudan. }\end{array}$ \\
\hline \multicolumn{3}{|l|}{ Western Africa } \\
\hline Dai (2011) & Western Africa - Sahel: 1970s, 1980s & $\begin{array}{l}\text { These droughts were attributed to a southward shift of the warmest SSTs in the Atlantic and } \\
\text { warming in the Indian Ocean. }\end{array}$ \\
\hline Druyan (2011) & Western Africa - Sahel: 1970s, 1980s & $\begin{array}{l}\text { No trend in future droughts in Sahel in late } 21 \text { st century. Some studies say wet and some dry } \\
\text { conditions. }\end{array}$ \\
\hline Giannini et al. (2008) & Western Africa - Sahel: 1970s, 1980s & $\begin{array}{l}\text { The study investigates the droughts in Sahel during } 1970 \text { s and } 1980 \text { s using global climate models. } \\
\text { The results suggest that the origin of these droughts is global in scale and external to the region. } \\
\text { These droughts are attributed to warming of tropical oceans, especially the pacific and Indian } \\
\text { Oceans, superimposed on an enhanced warming of the Southern Hemisphere compared to the } \\
\text { Northern Hemisphere most evident in Atlantic. Land surface changes, driven by precipitation } \\
\text { changes and also anthropogenic activities, may have acted to amplify these droughts. }\end{array}$ \\
\hline Kasei et al. (2010) & $\begin{array}{l}\text { Western Africa - Burkina Faso, Ghana, Mali, Togo, } \\
\text { Volta Basin: 1961, 1970, 1983, 1984, 1992, } 2001 .\end{array}$ & $\begin{array}{l}\text { Using rainfall data of } 1961 \text { to } 2005 \text {, intensity, extent and recurrence frequency was estimated using } \\
\text { SPI as a drought indicator. The } 1983-1984 \text { drought was most severe covering } 90 \% \text { of the basin } \\
\text { area. Akosomombo lake recorded lowest flows during } 1983 \text {. The study show that dry years have } \\
\text { become more frequent and occur at shorter intervals. Areal coverage of drought has also increased. }\end{array}$ \\
\hline Mishra and Singh (2010) & $\begin{array}{l}\text { Western Africa - Sahel: 1910s, 1940s, 1960s, 1970s, } \\
1980 \text { s }\end{array}$ & $\begin{array}{l}\text { The study reviews drought concepts and provides a critical evaluation of the most widely used } \\
\text { indicators for drought assessment. But the review remains limited in terms of description of the } \\
\text { historic droughts and only briefly mentions few of them with their main impacts and recommends } \\
\text { further work in this direction. }\end{array}$ \\
\hline Lebel et al. (2009) & Western Africa - Sahel: 1970s, 1980s & $\begin{array}{l}\text { A wealth of data is collected under AMMA-Catch case sites in Mali, Niger and Benin on land sur- } \\
\text { face processes and atmospheric dynamics. This will help in better understanding the interactions } \\
\text { between atmospheric, oceanic and terrestrial systems enabling a better understanding and } \\
\text { prediction of rainfall in this region. }\end{array}$ \\
\hline Shanahan et al. (2009) & $\begin{array}{l}\text { Western Africa - Lake Bosumtwi, Ghana: 1970s Sahel } \\
\text { drought }\end{array}$ & $\begin{array}{l}\text { The study indicates that the severe droughts of Sahel in 1970s is not anomalous in the context } \\
\text { of past three millennia and monsoon is capable of longer and more sever future droughts. The } \\
\text { findings are based on sediment analysis from Lake Bosumtwi in Ghana. }\end{array}$ \\
\hline Zeng (2003) & Western Africa - Sahel: Late 1960s onward. & $\begin{array}{l}\text { The study shows lower rainfall in Sahel since } 1960 \text { s but the exact drought years are not men- } \\
\text { tioned. The study focuses on reviewing the existing evidence on causes of droughts in Sahel. The } \\
\text { study shows that combination of various factors are responsible for droughts in Sahel and are not } \\
\text { yet fully understood and thus could not be adequately predicted. Therefore, a combination of im- } \\
\text { proved climatic predictions, sensible land use practices and green house gas emission reductions } \\
\text { are very important for the future of this region. }\end{array}$ \\
\hline \multicolumn{3}{|l|}{ Eastern Africa } \\
\hline Anderson et al. (2012) & $\begin{array}{l}\text { Eastern Africa: 2010-2011 drought in Ethiopia, Soma- } \\
\text { lia and Kenya }\end{array}$ & $\begin{array}{l}\text { The study demonstrated the usefulness of remotely sensed data and hydrological modelling for } \\
\text { tracking the progression and severity of drought. }\end{array}$ \\
\hline Dutra et al. (2013) & Horn of Africa: 2010-2011 in Ethiopia and Somalia & $\begin{array}{l}\text { The study shows that drought was caused by lack of rainfall in both the October-December (short } \\
\text { rainfall) and March-May (long rainfall) seasons. The drought was attributed to La Niña } \\
\text { conditions. This drought was well forecasting by the European Centre for Medium-Range Weather } \\
\text { Forecasts (ECMWF) forecasting system. }\end{array}$ \\
\hline Hastenrath et al. (2007) & Eastern Africa - Kenya: 2005 & $\begin{array}{l}\text { Drought was attributed to increased pressure in the west and accelerated westerlies (wind) } \\
\text { anomalies }\end{array}$ \\
\hline Ntale and Gan (2003) & Eastern Africa - Kenya and Tanzania: 1949-1950. & $\begin{array}{l}\text { The study reviewed various drought indicators and compared the performance of the PDSI, } \\
\text { Bhalme-Mooley Index (BMI) and standardized precipitation index (SPI). Different indicators may } \\
\text { yield different drought results. SPI was recommended for eastern Africa. }\end{array}$ \\
\hline Rulinda et al. (2012) & $\begin{array}{l}\text { Eastv Africa - Burundi, Kenya, Rwanda, Tanzania, } \\
\text { Uganda: 2005-2006 }\end{array}$ & $\begin{array}{l}\text { Analyzed spatial propagation of vegetative drought during September } 2005 \text { to April } 2006 \text { using } \\
\text { 10-day NOAA AVHRR images. The drought reached peak in January } 2006 .\end{array}$ \\
\hline Tierney et al. (2013) & Eastern Africa - Horn of Africa: 2010-2011 & $\begin{array}{l}\text { This drought was regarded as the worst during the past } 60 \text { years. The study concluded that the } \\
\text { Indian Ocean SSTs are the primary influence on East African rainfall over multi-decadal and } \\
\text { perhaps longer timescales. }\end{array}$ \\
\hline
\end{tabular}


Table 2. Continued.

\begin{tabular}{|c|c|c|}
\hline Reference & $\begin{array}{l}\text { Drought enlisted by region/country/basin during } 1900 \\
\text { to } 2013\end{array}$ & Remarks \\
\hline \multicolumn{3}{|l|}{ Southern Africa } \\
\hline Belbase and Morgan (1994) & $\begin{array}{l}\text { Southern Africa - Botswana: } 1978-1979,1982-1987 \text {, } \\
\text { 1991-1992. }\end{array}$ & $\begin{array}{l}\text { The case study highlights the salient features of the relatively successful drought management } \\
\text { experience in Botswana. }\end{array}$ \\
\hline Manatsa et al. (2008) & $\begin{array}{l}\text { Southern Africa - Zimbabwe: 1902-1903, 1911- } \\
\text { 1916, 1926-1927, 1941-1942, 1963-1964, 1972-1973, } \\
\text { 1982-1984, 1986-1987, 1991-1992 }\end{array}$ & $\begin{array}{l}\text { The study identified droughts in Zimbabwe based on SPI estimation from the regionally averaged } \\
\text { rainfall for the period 1900-2000. The moderate to severe droughts are noted here, with 1991- } \\
1992 \text { as the most extreme drought of the 20th century. The study indicate that El Niño-Southern } \\
\text { Oscillation (ENSO) alone is not a sufficient predictor of droughts; furthermore, it shows that the } \\
\text { March-June extreme positive Darwin sea level pressure anomalies are ideal additional candidate } \\
\text { for drought monitoring and forecasting in Zimbabwe and southern Africa. }\end{array}$ \\
\hline Msangi (2004). & $\begin{array}{l}\text { Southern Africa: 1902, 1909-1911, 1917-1918, 1921- } \\
\text { 1922, 1925, 1929, 1933-1934, 1939-1940, 1953, 1969, } \\
\text { 1972-1973, 1976, 1980-1982, 1984-1985 }\end{array}$ & $\begin{array}{l}\text { Information on drought years and respective country is not given. The study mainly focused on } \\
\text { analyzing the drought management efforts by international and regional organizations, national } \\
\text { institutions and NGOs and communities. The study stressed the need for adopting people centred } \\
\text { mitigation measures and calling for informed global action as the success lies with people in the } \\
\text { south and those in the north. }\end{array}$ \\
\hline Mussá et. al. (2014) & $\begin{array}{l}\text { South Africa, Crocodile River catchment: 1945, 1951, } \\
\text { 1958, 1966, 1970-1971, 1978, 1983-1984, 1992-1995 } \\
\text { and 2003-2004 }\end{array}$ & $\begin{array}{l}\text { The main focus of the study is to analyze whether groundwater can be used as an emergency } \\
\text { source of water in cases of severe droughts in the Crocodile catchment. The study used the SPI } \\
\text { and SRI drought indicators to identify meteorological and hydrological droughts, respectively. It } \\
\text { implies that the 1992-1995 drought was the most severe one in the last } 70 \text { years where the upper } \\
\text { and lower areas of the catchments were the most affected. }\end{array}$ \\
\hline Richard et al. (2001) & $\begin{array}{l}\text { Southern Africa: } 1951,1960,1964,1965,1968,1970 \text {, } \\
1973,1982,1983,1987\end{array}$ & $\begin{array}{l}\text { Droughts were not referred per country. The study focused on analyzing droughts from } 1950 \\
\text { to } 1988 \text { during the summer rainfall period January-March. Droughts during } 1970-1988 \text { period } \\
\text { were intense and widespread compared to those during 1950-1969. The ENSO was the main } \\
\text { governing factor for droughts during 1970-1988 (though not always), whereas regional oceanic } \\
\text { and atmospheric anomalies (e.g. southwest Indian Ocean SST) were the main causes. }\end{array}$ \\
\hline Rouault and Richard (2005) & $\begin{array}{l}\text { Southern Africa (south of } 10^{\circ} \mathrm{S} \text { ): 1906, 1916, 1924, } \\
\text { 1933, 1949, 1970,1983,1984, 1992, 1993, 1995, 1996, } \\
\text { 2002, 2003, 2004. }\end{array}$ & $\begin{array}{l}\text { The study discussed these droughts and corresponding area under them at an aggregated level of } \\
\text { the African continent. Country or regional estimates are not available. SPI estimates for the period } \\
1900-1999 \text { are used. The ENSO (El Niño conditions) was attributed to } 8 \text { out of these } 12 \text { droughts } \\
\text { occurred during 20th century. The area of the African continent under drought has significantly } \\
\text { increased, especially after 1980s. }\end{array}$ \\
\hline Vogel et al. (2010) & $\begin{array}{l}\text { Southern Africa: 1982-1993, 1991-1992, 1994-1995, } \\
\text { 2001-2003 }\end{array}$ & $\begin{array}{l}\text { This study stresses the need for learning from past drought events to better manage the future. The } \\
\text { response to drought and general management options practiced in Southern African Development } \\
\text { Community (SADC) countries are reviewed, in special reference to indicated droughts. }\end{array}$ \\
\hline \multicolumn{3}{|l|}{ More than one region } \\
\hline Calow et al. (2010) & $\begin{array}{l}2002-2003,2004-2005 \text { and } 2005-2006 \text { droughts in } \\
\text { Ethiopia; 1991-1992 drought in Lesotho, Malawi, } \\
\text { South Africa, Zimbabwe and Ghana. }\end{array}$ & $\begin{array}{l}\text { The study shows the impacts of droughts on groundwater resources and consequently on water } \\
\text { supply security. The communities enter into a spiral of water insecurity when shallow ground- } \\
\text { water supplies fail and additional demand on remaining resources causes mechanical failures. } \\
\text { Declining access to food and access to safe water are interrelated, but the later usually receive less } \\
\text { attention in drought management. Groundwater can act as buffer during droughts by increasing } \\
\text { the coverage of groundwater supplies to rural communities underpinned by sound hydrological } \\
\text { and socio-economic information. }\end{array}$ \\
\hline Couttenier and Soubeyran (2013) & Sub-Saharan Africa: 1980s. & $\begin{array}{l}\text { No country or year specific information presented, though droughts in Sudan in } 1980 \text { s and in } \\
\text { Uganda during } 1980 \text { s and } 2003-2005 \text { are linked to civil war. Overall, the link between drought } \\
\text { and civil war was described as weak. }\end{array}$ \\
\hline Rojas et al. (2011) & $\begin{array}{l}\text { Morocco: 1992, 1995, 1997; Tunisia and Algeria: 1999- } \\
\text { 2002; Sahel: early-mid 1980s; Ethiopia and Kenya: } \\
1984 \text { and 2000; Ethiopia, Eritrea and Somalia: 1987; } \\
\text { Southern Africa: 1982-1983 and 1991-1992 (most } \\
\text { countries). }\end{array}$ & $\begin{array}{l}\text { The study examined the major droughts that occurred on the African continent during 1980-2010. } \\
\text { The study proposed that the mixed Vegetation Health Index (VHI), estimated using remote-sensing } \\
\text { data (AVHRR) is a promising agricultural drought monitoring indicator and was able to track } \\
\text { major droughts during 1981-2009 reported in the selected literature. }\end{array}$ \\
\hline Tadesse et al. (2008) & $\begin{array}{l}\text { Sub-Saharan Africa: 1972-1974 and 1984-1985 (Sahel } \\
\text { and East Africa), 1992-1993 (southern Africa), 2000- } \\
2002 \text { (Horn of Africa) }\end{array}$ & $\begin{array}{l}\text { Droughts resulting in severe food shortages and famine are mentioned. The need for moving } \\
\text { from a crisis management to risk management approaches is stressed and the use of the available } \\
\text { drought and food security monitoring tools is recommended to reduce the impacts of droughts. }\end{array}$ \\
\hline Vicente-Serrano et al. (2012) & $\begin{array}{l}\text { Ethiopia, Sudan and Sahel region: 1974; Zimbabwe; } \\
\text { 1990-1991; Kenya: 1999-2001; Many countries: 1984; } \\
\text { Congo River: 1960s, 1970s; Orange River: 1980s, 1990s }\end{array}$ & $\begin{array}{l}\text { The study demonstrated how the development of drought information systems based on geospa- } \\
\text { tial technology, that combines static and real-time information could improve the possibilities of } \\
\text { drought mitigation in Africa. }\end{array}$ \\
\hline
\end{tabular}

Most African countries observe single and multi-year droughts when seen from purely hydro-climatic point of view. For instance, a number of severe droughts that occurred in northern and southern Africa during the 20th century are comparable to those observed in eastern and western Africa where comparatively more droughts are reported in literature and available databases (Tables 2 and 3). However, distinct geospatial and temporal patterns exist in the drought episodes mainly driven by the diverse nature of the climate and drought inducing physical mechanisms (discussed later in this paper). It can be inferred from the studies reviewed in this paper (Table 2) that the multi-year and prolonged droughts are more common in Sahel compared to any other regions (e.g. Mishra and Singh, 2010; Rojas et al., 2011). In contrast, studies for the eastern Africa report mostly very severe seasonal droughts often not spanning over many years (e.g. Dutra et al., 2013). 
Table 3. Summary of drought events recorded for 1900-2013 in EM-DAT database.

\begin{tabular}{|c|c|c|c|c|c|}
\hline Region/countries & Drought years & $\begin{array}{r}\# \text { of } \\
\text { events }\end{array}$ & $\begin{array}{r}\# \text { of } \\
\text { people killed }\end{array}$ & $\begin{array}{r}\text { \# of } \\
\text { people affected }\end{array}$ & $\begin{array}{r}\text { Economic damage } \\
\left(\left(\mathrm{USD} \times 10^{3}\right)\right.\end{array}$ \\
\hline Overall African Continent & & 291 & 847143 & 362225799 & 2920593 \\
\hline North Africa & & 18 & 150012 & 31153400 & 900100 \\
\hline Algeria & 1981,2005 & 2 & 12 & 0 & 0 \\
\hline Morocco & $1966,1971,1983,1984,1999$ & 5 & 0 & 412000 & 900100 \\
\hline Tunisia & 1977,1988 & 2 & 0 & 31400 & 0 \\
\hline Sudan & 1980, 1983, 1987, 1990, 1991, 1996, 1999, 2009, 2012 & 9 & 150000 & 30710000 & 0 \\
\hline Middle Africa & & 25 & 3058 & 11379800 & 84500 \\
\hline Angola & 1981, 1985, 1989, 1997, 2001, 2004, 2012 & 7 & 58 & 4443900 & 0 \\
\hline Cameroon & $1971,1990,2001,2005$ & 4 & 0 & 586900 & 1500 \\
\hline Central Africa Republic & 1983 & 1 & 0 & 0 & 0 \\
\hline Chad & $1910,1940,1966,1969,1980,1993,1997,2001,2012$ & 9 & 3000 & 5456000 & 83000 \\
\hline Congo & 1983 & 1 & 0 & 0 & 0 \\
\hline Sao Tome et Principe & 1983 & 1 & 0 & 93000 & 0 \\
\hline Zaire/Congo Dem Rep & 1978,1983 & 2 & 0 & 800000 & 0 \\
\hline West Africa & & 94 & 170012 & 74500255 & 507354 \\
\hline Benin & 1969,1980 & 2 & 0 & 2215000 & 651 \\
\hline Burkina Faso & 1910, 1940, 1966, 1969, 1976, 1980, 1988, 1990, 1995, 1998, 2001, 2011 & 12 & 0 & 8413290 & 0 \\
\hline Cape Verde Is & $1900,1910,1920,1940,1946,1969,1980,1992,1998,2002$ & 10 & 85000 & 40000 & 0 \\
\hline Cote d'Ivoire & 1980 & 1 & 0 & 0 & 0 \\
\hline Gambia The & $1910,1940,1968,1969,1976,1980,2002,2012$ & 8 & 0 & 1258000 & 700 \\
\hline Ghana & $1971,1977,1980$ & 3 & 0 & 12512000 & 100 \\
\hline Guinea & 1980,1998 & 2 & 12 & 0 & 0 \\
\hline Guinea Bissau & $1910,1940,1969,1980,1980,2002,2006$ & 6 & 0 & 132000 & 0 \\
\hline Liberia & 1980 & 1 & 0 & 0 & 0 \\
\hline Mali & $1910,1940,1966,1976,1980,1991,2001,2005,2006,2010,2011$ & 11 & 0 & 6927000 & 0 \\
\hline Mauritania & $1910,1940,1965,1969,1976,1978,1980,1993,1997,2001,2010,2011$ & 12 & 0 & 7398907 & 59500 \\
\hline Niger & $1903,1906,1910,1940,1966,1980,1988,1990,1997,2001,2005,2009,2011$ & 13 & 85000 & 23655058 & 0 \\
\hline Nigeria & 1981 & 1 & 0 & 3000000 & 71103 \\
\hline Senegal & $1910,1940,1966,1969,1976,1979,1980,2002,2011$ & 9 & 0 & 8399000 & 374800 \\
\hline Togo & $1971,1980,1989$ & 3 & 0 & 550000 & 500 \\
\hline East Africa & & 122 & 523561 & 220892229 & 371900 \\
\hline Burundi & $1999,2003,2005,2008,2009,2010$ & 6 & 126 & 3062500 & 0 \\
\hline Comoros & 1981 & 1 & 0 & 0 & 0 \\
\hline Djibouti & $1980,1983,1988,1996,1999,2005,2007,2008,2010$ & 9 & 0 & 1188008 & 0 \\
\hline Eritrea & $1993,1999,2008$ & 3 & 0 & 5600000 & 0 \\
\hline Ethiopia & $1965,1969,1973,1983,1987,1989,1997,1998,1999,2003,2005,2008,2009,2012$ & 15 & 402367 & 66941879 & 92600 \\
\hline Kenya & $1965,1971,1979,1983,1991,1994,1996,1999,2004,2005,2008,2010,2012$ & 13 & 196 & 47200000 & 1500 \\
\hline Madagascar & $1981,1988,2000,2002,2005,2008$ & 6 & 200 & 3515290 & 0 \\
\hline Malawi & $1987,1990,1992,2002,2005,2007,2012$ & 7 & 500 & 21578702 & 0 \\
\hline Mauritius & 1999 & 1 & 0 & 0 & 175000 \\
\hline Mozambique & $1979,1981,1987,1990,1998,2001,2003,2005,2007,2008,2010$ & 12 & 100068 & 17757500 & 50000 \\
\hline Rwanda & $1976,1984,1989,1996,1999,2003$ & 6 & 237 & 4156545 & 0 \\
\hline Somalia & $1964,1969,1973,1980,1983,1987,1988,1999.2004,2005,2008,2010,2012$ & 13 & 19673 & 13183500 & 0 \\
\hline Tanzania Uni Rep & $1967,1977,1984,1988,1990,1996,2003,2004,2006,2011$ & 10 & 0 & 12737483 & 0 \\
\hline Uganda & $1967,1979,1987,1998,1999,2002,2005,2008,2010$ & 9 & 194 & 4975000 & 1800 \\
\hline Zambia & $1981,1983,1990,1995,2005$ & 5 & 0 & 4173204 & 0 \\
\hline Zimbabwe & $1981,1990,1998,2001,2007,2010$ & 6 & 0 & 14822618 & 51000 \\
\hline Southern Africa & & 32 & 500 & 24300115 & 1056739 \\
\hline Botswana & $1965,1968,1970,1981,1990,2005$ & 6 & 0 & 1344900 & 3000 \\
\hline Lesotho & $1968,1983,1990,2002,2007,2011$ & 6 & 0 & 2736015 & 1000 \\
\hline Namibia & $1981,1990,1995,1998,2001,2002,2013$ & 7 & 0 & 1114200 & 51000 \\
\hline South Africa & $1964,1980,1981,1986,1988,1990,1995,2004$ & 8 & 0 & 17475000 & 1000000 \\
\hline Swaziland & $1981,1984,1990,2001,2007$ & 5 & 500 & 1630000 & 1739 \\
\hline
\end{tabular}

The geospatial spread of drought depicts large variation within a country or a basin, beside regional heterogeneity. This point is clearly indicated by Figs. 2 and 3 and also highlighted by other studies (e.g. Anderson et al., 2012; Moeletsi and Walker, 2012; Mussá et al., 2014; Rojas et al., 2011; Rulinda et al., 2012; Trambauer et al., 2014). The increasingly available information and tools based on remote sensing, analysis of global climatic data sets (e.g. global
SPEI products) and hydrological and climatic modelling offer great opportunity to identify these geospatial differences and drought hot spots. For instance, a remote-sensing-based study by Rojas et al. (2011) identified hot spots regions at sub-national level depicting higher probabilities of facing agricultural droughts. The studies indicate that the semiarid and sub-humid regions of Africa are the most drought prone regions (e.g. World Bank and GFDRR, 2010). These 
countries are highly vulnerable to drought owing to high climatic variability and also due to other reasons such as poverty, high dependency on rainfed agriculture and weak infrastructure to manage resources and recover from disasters. Moreover, vulnerability to drought varies per country. For instance, the economic impact of the 1991-1992 drought was much higher on the GDP of Malawi and Zimbabwe compared to South Africa and Botswana (Benson and Clay, 1998). The lowest negative impacts in Botswana on people's livelihoods and food security during drought periods of 1982-1987 and 1992 were mainly attributed to a small and largely accessible national population, availability of domestic and international resources, existence of rural infrastructure, government commitment, district-level capacity and a timely and fairly comprehensive food security and nutrition monitoring system (Belbase and Morgan, 1994).

There is increasing availability of drought monitoring and forecasting tools for decision making which can provide realtime monitoring and forecasting of drought across the region (e.g. Tadesse et al., 2008; Anderson et al., 2009; Dutra et al., 2013; Vicente-Serrano et al., 2012). However, the use of these tools in decision making is still limited and could be promoted. For instance, despite inherent uncertainties in the available drought monitoring and forecasting systems, the 2010-2011 drought in the Horn of Africa was well predicted by European Centre for Medium-Range Weather Forecasts (ECMWF). But this information was not timely used for better preparedness and mitigation of the drought, which finally caused heavy toll affecting about 12 million people (Dutra et al., 2013).

\subsection{Past, present and future pattern of droughts}

There are few studies available to date which offer possibility of comparing droughts observed during 1900-2013 (instrumental era) with those witnessed in the past centuries. This comparison is important as African climate displays high decadal and century-scale variability. The work of Touchen et al. $(2008,2011)$ provides a long-term perspective on droughts in northwestern Africa (Morocco, Algeria and Tunisia). They used tree-ring records to construct the PDSI for the period AD 1179 to 2002. These studies reveal that the frequency of occurrence of a single drought event was 12 to 16 times per century before the 20th century, which was increased to 19 during the 20th century. The most severe multiyear drought occurred during 1999-2002, whereas 1847 and 2002 were identified as the driest single years with PDSI values of -3.74 and -3.90 , respectively. The latter half of the 20th century is seen as the driest period in the last nine centuries. This shift to drier conditions was attributed to anthropogenic climate change.

A number of researchers studied historic droughts in Africa based on lake sediment analyses. Evidence from the sediment analysis of the Lake Bosumtwi, Ghana, indicated several prolonged periods of drought during the last three millennia, most recent ones around 200 to 300 years ago (Shanahan et al., 2009). Comparing 1970s droughts in Sahel with earlier drought episodes that occurred during the past three millennia, they concluded that more severe and prolonged droughts were recorded in the past centuries. Verschuren et al. (2000) investigated droughts over the period AD 900 to 2000 based on sediment analysis of Lake Naivasha, Kenya, in equatorial eastern Africa. The period AD 1000 to 1270 (Medieval Warm Period) was found to be the driest one over the last 1100 years. Additionally, dry conditions were found around AD 1380-1420, 1560-1620 and 1760-1840 during relatively wet period of AD 12701850 (Little Ice Age). These drought episodes were more severe than recorded droughts in the 20th century. Bessems et al. (2008) noted extreme droughts in equatorial eastern Africa about 200 years ago based on the sediment analysis of three lakes (Chibwera and Kanyamukali in western Uganda, and Baringo in central Kenya). The authors, Verschuren et al. (2000) and Bessems et al. (2008), compared their findings with the available evidence from the cultural history of eastern Africa and found consistency between two sets of observations.

Endfield and Nash (2002) described the discourse on longterm desiccation of the African continent emerged during 19th century. Their study is based on the analysis of the missionary documents from southern Africa (Botswana and South Africa). The authors constructed a chronology of intradecadal climatic variability for the period 1815-1900 and showed that the major multi-year droughts occurred in 1820$1827,1831-1835,1844-1851,1857-1865,1877-1886$ and 1894-1899. The study inferred that the discourse on longterm desiccation evolved during this period was merely triggered by these episodes of droughts rather than underpinned by long-term climatic deterioration. Nevertheless, the discourse on desiccation still remains an important subject in the current drought research. The evidence presented in the previous section pointed out to the increased aridity and intensification of droughts, especially during the second half of the 20th century (e.g. Dai, 2011; Elagib and Elhang, 2008; Kasei et al., 2010; Ouassou et al., 2007; Manatsa et al., 2008; Touchan et al., 2008, 2011; Richard et al., 2001). Dai (2013) predicted the likelihood of increased droughts and aridity over central and southern Africa during the 21 st century. On the contrary, the Sahel region may receive more rainfall. Large uncertainties exist in these findings and thus require caution in making regional or continental conclusions. Druyan (2011) reviewed 10 studies which are based on the simulations of atmosphere-ocean global climate models on future climate of Sahel. Some studies projected wetter conditions and some projected more frequent droughts, thus, no consensus was observed. The large uncertainties and differences in these predictions were attributed to model limitations and complexity of many physical mechanisms governing the precipitation trends. 


\subsection{Causes of droughts}

Drought is a part of natural climatic variability on the African continent, which is quite high at intra-annual, inter-annual, decadal and century timescales (e.g. Nicholson, 2000). Many studies attempted to investigate the natural causes that could be associated with droughts in Africa (Caminade and Terray, 2010; Dai, 2011, 2013; Dutra et al., 2013; Giannini et al., 2008, 2013; Hastenrath et al., 2007; Herweijer and Seager, 2008; Jury et al., 1996; Kerr, 1985; Lebel et al., 2009; Manatsa et al., 2008; Nicholson, 2000; Richard et al., 2001; Shanahan et al., 2009; Tierney et al., 2013; VicenteSerrano, 2012; Zeng, 2003). Some of them also focus on anthropogenic factors, such as climate change, aerosol emissions, land use practices and resulting land-atmosphere interactions, contributing to drought inducing mechanisms (e.g. Dai, 2011, 2013; Hwang et al., 2013; Lebel et al., 2009; Zeng, 2003). The review of these studies revealed that there are a number of factors contributing to inducing drought conditions. However, despite regional differences in the factors causing droughts in a specific region, El Niño-Southern Oscillation (ENSO) and SSTs are regarded major influencing factors across the continent. For instance, Nicholson (2000) demonstrates that ENSO, SST and land-atmospheric feedback are the major governing factors on the rainfall variability in Africa. The author states that these factors alone or in combination can change the atmospheric dynamics and circulation patterns, for instance, causing changes in the Hadley and Walker circulations or upper level jet streams.

Droughts in southern Africa occur most of the time during the warm phase of ENSO (El Niño Southern Oscillation). Nicholson and Kim (1997) studied the correlation between precipitation and ENSO in the Pacific. They found that among the 20 extreme rainfall events analyzed, 15 events appeared to be modulated by the ENSO. Their results suggest that the southern part of Africa is negatively correlated with warm ENSO. Phillips et al. (1998) studied the possibility of using ENSO predictions to reduce the risks associated with rainfall variability in agricultural production in Zimbabwe. The analysis showed that during the El Niño phase, a decrease on the precipitation was noticed, which is in agreement with the findings of Nicholson and Kim (1997). Rouault and Richard (2005) studied the temporal and spatial extent of the drought in South Africa based on the SPI (standardized precipitation index) from 1900 to 2004. Their results show that 8 out of 12 droughts detected coincide with El Niño years, which confirms the strong relationship between the ENSO and the droughts events in southern Africa. However, some studies point to the fact that the occurrence of droughts during El Niño years does not always happen, as there are many other local and global factors influencing the drought phenomenon. Richard et al. (2001) examined droughts during 1950 to 1988 in southern Africa. They found that droughts during 1970-1988 were intense and widespread compared to those during 1950-1969. The
El Niño was the main governing factor for droughts during 1970-1988; however, this observation requires caution because droughts may not occur during El Niño periods, i.e. as happened during 1925-1926 and 1997-1998. For the droughts during 1950-1969, regional oceanic and atmospheric anomalies (e.g. southwest Indian Ocean SST) were named as the main causes. Manatsa et al. (2008) suggested that El Niño alone is not a sufficient predictor of droughts in southern Africa. They recommend that March to June extreme positive Darwin sea level pressure anomalies are ideal additional candidate for drought monitoring and forecasting in Zimbabwe and southern Africa.

Contrary to southern Africa, eastern Africa faces droughts during cold phase of ENSO (La Niña). For instance, Dutra et al. (2013) indicated that strong La Niña event was the main cause of 2010-2011 drought in the Horn of Africa. Lott et al. (2013) investigated whether the 2010-2011 drought was caused by human intervention or not. They did not find any evidence of human activities on this event and also attributed this with La Niña events. Tierney et al. (2013) also suggested that the recent drought in the Horn of Africa, was partly due to the prevailing La Niña conditions in the tropical Pacific. On the other hand, Hasternath et al. (2007) argue that the low rainfall in this region occurs during fast westerlies which are usually accompanied by anomalously cold waters in the northwestern and warm anomalies in the southeastern extremity of the equatorial Indian Ocean basin. This mechanism was found to be responsible for 2005 drought in the Horn of Africa. Tierney et al. (2013) suggested that the Indian Ocean drives rainfall variability in eastern Africa by altering the local Walker circulation. Moreover, it is argued that warming of the central Indian Ocean accelerated by greenhouse gas and aerosol emissions after the latter half of the 20th century are correlated with the decline in precipitation over eastern Africa (Funk et al., 2008; Williams and Funk, 2011). These studies suggested that warming of the central Indian Ocean drives changes in the local Walker circulation causing reduction in the seasonal rainfall and inducing drought conditions in the region.

Droughts in Sahel are caused by an array of complex processes and feedback mechanisms. Caminade and Terray (2010) stated that conditions that favour lower summer rainfall in Sahel are when Atlantic Ocean north of equator is cool and south of the equator is warm, El Niño events and increased vertical thermal stability from a warming troposphere. Most of the studies on Sahel droughts concur that the recent severe droughts in Sahel were caused by the ocean warming (southward warming gradient of the Atlantic ocean and steady warming of the Indian Ocean) and a southward shift of inter-tropical convergence zone (ITCZ) (Caminade and Terry, 2010; Dai, 2011; Giannini et al., 2008; Janicot et al., 1998; Kerr, 1985; Lebel et al., 2009; Zeng, 2003). The land-atmosphere feedbacks through natural vegetation and land cover change are also important factors. Anthropogenic contribution in land use change altering the land surface 
feedback mechanisms is also seen as a factor. Some studies were done with the objective of examining whether the climate in the Sahel region is sensitive to land use changes or not. For instance, Zheng and Eltahir (1997) investigated the interaction between vegetation and climate in the Sahel region by means of simulations of the West African monsoons with a simple zonally symmetric model. Their results show that the impacts of land cover changes in the Sahel region along the border with Sahara are insignificant. However, deforestation along the southern coast of West Africa can cause significant reduction of the rainfall and effect on the monsoon circulation. Several studies suggested aerosol emissions were an important driver of the recent Sahel droughts (e.g. Desboeufs et al., 2010; Hwang et al., 2013; Moulin and Chiapello, 2004; Prospero and Lamb, 2003). Furthermore, human induced green house gas emission is also considered as a contributory factor to oceans warming (e.g. Dai, 2013). Despite recognition of these anthropogenic factors, their relative contribution compared to natural factors in inducing Sahel droughts is debated and regarded as a secondary factor.

The limited studies are available on causes of droughts in northwestern Africa. The North Atlantic Ocean SST does have an influence on rainfall variability in the region but this relationship is rather weak and could not explain major droughts in the region ( $\mathrm{Li}$ et al., 2003; Touchan et al., 2011). Similarly, ENSO is seen as a potential factor, but a strong relationship is not demonstrated by ENSO for modulating droughts in this region (Esper et al., 2007; Touchan et al., 2008). The North Atlantic Oscillation (NAO) indicates variable influence on the rainfall in the region, with negative correlation with western parts but no correlation with eastern parts (Touchan et al., 2011). However, no relationship is found between NAO and droughts in the region. Touchan et al. (2011) argued that anthropogenic green house gas emission is an important factor causing drying in this region. The review of these studies suggested that the causes of droughts in northwestern Africa are not well established and require further research.

\section{Conclusions}

The climate of the African continent exhibits large geospatial and temporal variability. Droughts are recurrent features varying from lack of rain in one season or up to one or more years. The vulnerability to droughts is high due to poverty, large dependency on rainfed agriculture and other factors. Therefore, droughts continue to incur a heavy toll to people, animals, environment and economy. The planning and management of droughts requires a paradigm change shifting from crisis management to risk management. Comprehensive studies on historic drought events could significantly guide better planning and mitigation strategies of droughts. There is a significantly increasing number of scientific studies and information on various aspects of drought. However, these studies do not provide a long-term and/or continentalscale perspective. This study is a first of its kind to build such a perspective on droughts in Africa with the aim on conducting geospatial and long-term analysis of the droughts. The study is underpinned by a comprehensive review of available information and scientific literature and analysis of the EM-DAT and SPEI data sets.

The analysis of droughts during 1900-2013 indicated that droughts have intensified in terms of their frequency, severity and geospatial coverage over the last few decades. The droughts that occurred in 1972-1973, 1983-1984 and 19911992 were most intense and widespread. All of the regions witnessed severe droughts in the last few decades, for instance, the 2010-2011 drought in East Africa (Horn of Africa), 1999-2002 drought in North Africa, 2001-2003 drought in southern Africa and persistent droughts in Sahel during 1970s and 1980s. Few studies are available to construct drought chronologies before the 20th century. However, studies based on lake sediment analysis indicated episodes of severe droughts prolonged for decades and even centuries in the past over West and equatorial eastern Africa, which are also documented in the cultural histories of these regions. The studies underpinned by tree-ring chronologies in northwestern Africa indicated quite a number of moderate to severe droughts in the past, about 12-16 events per century which has increased to 19 during the 20th century. Southern Africa also faced several single and multi-year droughts during the 19th century, as indicated by the analysis of missionaries' correspondence.

Drought predictions based on the global climate models simulations show varying results and thus remain uncertain for most of the African continent. However, the results of simulation models suggested a high likelihood of increased droughts in central and southern Africa. Despite considerable improvements in these models, they are still not able to accurately represent the large number of complex factors responsible for causing the droughts across various regions of the continent (e.g. ENSO and SSTs, wind and pressure anomalies, land-atmospheric feedback mechanisms). Their complex interactions induce uncertainty in the drought predictions.

The available evidence from the past clearly shows that the African continent is very likely to face extreme and widespread droughts in the future. The vulnerability is likely to increase due to fast growing populations, increasing water demands and degradation of land and environmental resources. Addressing such a daunting and evident challenge calls for much more serious and committed action from communities, governments, regional bodies, international organizations and donors than what is witnessed at present. This review advances available information and scientific understanding of the droughts in Africa. 
Acknowledgements. This study was carried out in the scope of the DEWFORA (improved drought early warning and forecasting to strengthen preparedness and adaptation to droughts in Africa) project which is funded by the Seventh Framework Programme for Research and Technological Development (FP7) of the European Union (grant agreement no: 265454).

Edited by: F. Pappenberger

\section{References}

Anderson, W. B., Zaitchik, B. F., Hain, C. R., Anderson, M. C., Yilmaz, M. T., Mecikalski, J., and Schultz, L.: Towards an integrated soil moisture drought monitor for East Africa, Hydrol. Earth Syst. Sci., 16, 2893-2913, doi:10.5194/hess-16-28932012, 2012.

Barbosa, P., Naumann, G., Valentini, L., Vogt, J., Dutra, E., Magni, D., and De Jager, A.: A Pan-African map viewer for drought monitoring and forecasting, 14th Waternet Symposium, Dar es Salaam, Tanzania, 30 October to 1 November 2013.

Belbase, K. and Morgan, R.: Food security and nutrition monitoring for drought relief management: The case of Botswana, Food Pol., 19, 285-300, doi:10.1016/0306-9192(94)90076-0, 1994.

Benson, C. and Clay, E.: The Impact of Drought on Sub-Saharan African Economies. A Preliminary Examination, World Bank Technical Papers, 1998.

Bessems, I., Verschuren, D., Russell, J. M., Hus, J., Mees, F., and Cumming, B. F.: Palaeolimnological evidence for widespread late 18th century drought across equatorial East Africa, Palaeogeogr. Palaeoclim. Palaeoecol., 259, 107-120, 2008.

Calow, R. C., Macdonald, A. M., Nicol, A. L., and Robins, N. S.: Ground water security and drought in Africa: linking availability, access, and demand, Ground Water, 48, 246-256, doi:10.1111/j.1745-6584.2009.00558.x., 2010.

Caminade, C. and Terray, L.: Twentieth century Sahel rainfall variability as simulated by ARPEGE AGCM, and future changes, Clim. Dynam., 35, 75-94, 2010.

Clarke, C. L., Shackleton, S. E., and Powell, M.: Climate change perceptions, drought responses and views on carbon farming amongst commercial livestock and game farmers in the semiarid Great Fish River Valley, Eastern Cape province, South Africa, Afr. J. Range Forage Sci., 29, 13-23, doi:10.2989/10220119.2012.687041, 2012.

Cornforth, R.: Weathering the drought in Africa, Planet Earth, Issue SPRING, March 2013, 30-31, 2013.

Couttenier, M. and Soubeyran, R.: Drought and Civil War in Sub-Saharan Africa, The Economic J., 24, 201-244, doi:10.1111/ecoj.12042, 2013.

Dai, A.: Drought under global warming: a review, Wiley Interdisciplinary Reviews, Clim. Change, 2, 45-65, doi:10.1002/wcc.81, 2011.

Dai, A.: Increasing drought under global warming in observations and models, Nat. Clim. Change, 3, 5258, http://www.nature.com/nclimate/journal/v3/n1/abs/ nclimate1633.html\#supplementary-information, 2013.
Desboeufs, K., Journet, E., Rajot, J.-L., Chevaillier, S., Triquet, S., Formenti, P., and Zakou, A.: Chemistry of rain events in West Africa: evidence of dust and biogenic influence in convective systems, Atmos. Chem. Phys., 10, 9283-9293, doi:10.5194/acp10-9283-2010, 2010.

Dondero, T. J.: Nutrition and health needs in drought-stricken Africa, Public Health Rep, 100, 634-638, 1985.

Druyan, L. M.: Studies of 21st-century precipitation trends over West Africa, Int. J. Climatol., 31, 1415-1424, doi:10.1002/joc.2180, 2011.

Dube, L. T. and Jury, M. R.: The Nature of Climate variability and impacts of drought over Kwazulu-Natal, South Africa, South Afr. Geograph. J., 82, 44-53, doi:10.1080/03736245.2000.9713692, 2000.

Dube, L. T. and Jury, M. R.: Meteorological structure of the 1992/93 drought over Eastern South Africa from ECMWF and satellite OLR analyses, South Afr. Geograph. J., 84, 170-181, doi:10.1080/03736245.2002.9713768, 2002.

Dube, L. T. and Jury, M. R.: Structure and precursors of the 1992/93 drought in KwaZulu-Natal, South Africa from NCEP reanalysis data, WaterSA, 29, 201-208, doi:10.4314/wsa.v29i2.4857, 2003.

Dutra, E., Magnusson, L., Wetterhall, F., Cloke, H. L., Balsamo, G., Boussetta, S., and Pappenberger, F.: The 2010-2011 drought in the Horn of Africa in ECMWF reanalysis and seasonal forecast products, International J. Climatol., 33, 1720-1729, doi:10.1002/joc.3545, 2013.

Elagib, N. A. and Elhag, M. M.: Major climate indicators of ongoing drought in Sudan, J. Hydrol., 409, 612-625, http://dx.doi. org/10.1016/j.jhydrol.2011.08.047, 2011.

EM-DAT: The International Disaster Database: http://www.emdat. be/glossary/9\#letterd (last access: 13 January 2014), 2009.

Endfield, G. H. and Nash, D. J.: Drought, desiccation and discourse: Missionary correspondence and nineteenth-century climate change in central southern Africa, Geograph. J., 168, 3347, 2002.

Esper, J., Frank, D., Büntgen, U., Verstege, A., Luterbacher, J., and Xoplaki, E.: Long-term drought severity variations in Morocco, Geophys. Res. Lett., 34, L17702, doi:10.1029/2007GL030844, 2007.

Falkenmark, M. and Rockström, J.: Building resilience to drought in desertification-prone savannas in Sub-Saharan Africa: The water perspective, Nat. Resour. Forum, 32, 93-102, doi:10.1111/j.1477-8947.2008.00177.x, 2008.

Funk, C., Dettinger, M. D., Michaelsen, J. C., Verdin, J. P., Brown, M. E., Barlow, M., and Hoell, A.: Warming of the Indian Ocean threatens eastern and southern African food security but could be mitigated by agricultural development, Sustainability Science, P. Natl. Acad. Sci., 105, 11081-11086, doi:10.1073/pnas.0708196105, 2008.

GFDRR (Global Facility for Disaster Reduction and Recovery): Disaster Risk Management Progra ms for Priority Countries, Washington, DC: World Bank, available at: http://gfdrr.org/sites/ gfdrr.org/files/publication/DRM_CountryPrograms_2011.pdf, 2011.

Giannini, A., Biasutti, M., and Verstraete, M. M.: A climate modelbased review of drought in the Sahel: Desertification, the regreening and climate change, Global Planet. Change, 64, 119$128,2008$. 
Giannini, A., Salack, S., Lodoun, T., Ali, A., Gaye, A. T., and Ndiaye, O.: A unifying view of climate change in the Sahel linking intra-seasonal, interannual and longer time scales, Environ. Res. Lett., 8, 024010, doi:10.1088/1748-9326/8/2/024010, 2013.

Gibbs, W. J. and Maher, J. V.: Rainfall Deciles as Drought Indicators, Bureau of Meteorology Bull. 48, Commonwealth of Australia, Melbourne, Australia, 1967.

Govaerts, Y. and Lattanzio, A.: Estimation of surface albedo increase during the eighties Sahel drought from Meteosat observations, Global Planet. Change, 64, 139-145, doi:10.1016/j.gloplacha.2008.04.004, 2008.

Green, R. H.: The political economy of drought in Southern Africa 1991-1993, Health Pol. Plann., 8, 255-266, doi:10.1093/heapol/8.3.255, 1993.

Hastenrath, S., Polzin, D., and Mutai, C.: Diagnosing the 2005 Drought in Equatorial East Africa, J. Climate, 20, 4628-4637, doi:10.1175/jcli4238.1, 2007.

Herweijer, C. and Seager, R.: The global footprint of persistent extra-tropical drought in the instrumental era, Int. J. Climatol., 28, 1761-1774, doi:10.1002/joc.1590, 2008.

Hwang, Y.-T., Frierson, D. M. W., and Kang, S. M.: Anthropogenic sulfate aerosol and the southward shift of tropical precipitation in the late 20th century, Geophys. Res. Lett., 40, 1-6, doi:10.1002/grl.50502, 2013

IFAD (International Fund for Agricultural Development): Climate Change Strategy, available at: http://www.ifad.org/climate/ strategy/e.pdf (last access: 30 January 2014), 2010.

IFAD (International Fund for Agricultural Development): Addressing climate change in west and central Africa, available at: http://www.ifad.org/operations/projects/regions/pa/pub/ climate.pdf (last access: 30 January 2014), 2011a.

IFAD (International Fund for Agricultural Development): Addressing climate change in in east and southern Africa, available at: http://www.ifad.org/operations/projects/regions/pf/pub/ climate.pdf (last access: 30 January 2014), 2011b.

Jager, J. M. D., Potgieter, A. B., and Berg, W. J. v. d.: Framework for forecasting the extent and severity of drought in maize in the Free State Province of South Africa, Agr. Syst., 57, 351-365, doi:10.1016/S0308-521X(98)00023-7, 1998.

Janicot, S., Harzallah, A., Fontaine, B., and Moron, V.: West African Monsoon Dynamics and Eastern Equatorial Atlantic and Pacific SST Anomalies (1970-88), J. Climate, 11, 1874-1882, 1998.

Jury, M. R., Pathack, B., De W Rautenbach, C. J., and Vanheerden, J.: Drought over South Africa and Indian Ocean SST: Statistical and GCM results, Global Atmos. Ocean Syst., 4, 47-63, 1996.

Kasei, R., Diekkrüger, B., and Leemhuis, C.: Drought frequency in the Volta Basin of West Africa, Sustain. Sci., 5, 89-97, doi:10.1007/s11625-009-0101-5, 2010.

Kerr, R. A.: Fifteen years of African drought, Science, 227, 14531454 doi:10.1126/science.227.4693.1453, 1985.

Lebel, T., Cappelaere, B., Galle, S., Hanan, N., Kergoat, L, Levis, S., Vieux, B., Descroix, L., Gosset, M., Mougin, E., Peugeot, C. and Seguis, L. AMMA-CATCH studies in the Sahelian region of West-Africa: An overview, J. Hydrol., 375, 3-13, doi:10.1016/j.jhydrol.2009.03.020, 2009.

Li, S., Robinson, W. A., and Peng, S.: Influence of the North Atlantic SST tripole on northwest African rainfall, Geophys. Res., 108, 4594, doi:10.1029/2002JD003130, 2003.
Lodoun, T., Giannini, A., Traoré, P. S., Somé, L., Sanon, M., Vaksmann, M., and Rasolodimby, J. M.: Changes in seasonal descriptors of precipitation in Burkina Faso associated with late 20th century drought and recovery in West Africa, Environ. Develop., 5, 96-108, doi:10.1016/j.envdev.2012.11.010, 2013.

Logar, I. and van den Bergh, J. C. J. M.: Methods to Assess Costs of Drought Damages and Policies for Drought Mitigation and Adaptation: Review and Recommendations, Water Resour. Manage., 27, 1707-1720, doi:10.1007/s11269-012-0119-9, 2013.

Lott, F., Christidis, N., Stott, P. A.: Can the 2011 East African drought be attributed to human-induced climate change?, Geophys. Res. Lett., 40, 1177-1181, doi:10.1002/grl.50235, 2013.

Manatsa, D., Chingombe, W., Matsikwa, H., and Matarira, C. H.: The superior influence of Darwin Sea level pressure anomalies over ENSO as a simple drought predictor for Southern Africa, Theor. Appl. Climatol., 92, 1-14, doi:10.1007/s00704-007-03153, 2008 .

Masih, I., Uhlenbrook, S., Maskey, S., and Smakhtin, V.: Streamflow trends and climate linkages in the Zagros Mountain, Iran. Clim. Change, 104, 317-338, doi:10.1007/s10584-009-9793-x, 2011.

McKee, T. B., Doesken, N. J., and Kleist J.: The relation of drought frequency and duration to time scales, in: Eighth Conference on Applied Climatology, edited by: Department of Atmospheric Science \& C. S. University, Anaheim, California, 1993.

Mishra, A. K. and Singh, V. P.: A review of drought concepts, J. Hydrol., 391, 202-216, doi:10.1016/j.jhydrol.2010.07.012, 2010.

Moeletsi, M. E. and Walker, S.: Assessment of agricultural drought using a simple water balance model in the Free State Province of South Africa, Theor. Appl. Climatol., 108, 425-450, doi:10.1007/s00704-011-0540-7, 2012.

Moulin, C. and Chiapello, I.: Evidence of the control of summer atmospheric transport of African dust over the Atlantic by Sahel sources from TOMS satellites (1979-2000), Geophys. Res. Lett., 31, L02107 doi:10.1029/2003g1018931, 2004.

Msangi, J. P.: Drought Hazard and Desertification Management in the Drylands of Southern Africa, Environ. Monit. Assess., 99, 75-87, doi:10.1007/s10661-004-4002-x, 2004.

Mussá, F. E. F., Zhou, Y., Maskey, S., Masih, I., and Uhlenbrook, S. Groundwater as an emergency source for drought mitigation in the Crocodile River catchment, South Africa, Hydrol. Earth Syst. Sci. Discuss., 11, 2719-2757, doi:10.5194/hessd-11-2719-2014, 2014.

Naumann, G., Barbosa, P., Carrao, H., Singleton, A., and Vogt, J.: Monitoring Drought Conditions and Their Uncertainties in Africa Using TRMM Data, J. Appl. Meteorol. Climatol., 51, 1867-1874, doi:10.1175/jamc-d-12-0113.1, 2012.

Nicholson, S. E.: The nature of rainfall variability over Africa on time scales of decades to millenia, Global Planet. Change, 26, 137-158, 2000.

Nicholson, S. E. and Kim, J.: The relationship of the El Niñosouthern oscillation to African rainfall, Int. J. Climatol., 17, 117135, 1997.

Ntale, H. K. and Gan, T. Y.: Drought indices and their application to East Africa, Int. J. Climatol., 23, 1335-1357, doi:10.1002/joc.931, 2003. 
O'Meagher, B., du Pisani, L. G., and White, D. H.: Evolution of drought policy and related science in Australia and South Africa, Agr. Syst., 57, 231-258, doi:10.1016/S0308-521X(98)00017-1, 1998.

Ouassou, A., Ameziane, T., Ziyad, A., and Belghiti, M.: Application of the Drought Management Guidelines in Morocco, Options Méditerranéennes, Series B, No., 58, 343-372, 2007.

Palmer, W. C.: Keeping track of crop moisture conditions, nationwide: the new crop moisture index, Weatherwise, 21, 156-161, 1968.

Phillips, O. L., Malhi, Y., Higuchi, N., Laurance, W. F., Núñez, P. V., Vásquez, R. M., Laurance, S. G., Ferreira, L. V., Stern, M., Brown, S., and Grace, J.: Changes in the Carbon Balance of Tropical Forests: Evidence from Long-Term Plots, Science, 282, 439-442, doi:10.1126/science.282.5388.439, 1998.

Prospero, J. M. and Lamb, P. J.: African Droughts and Dust Transport to the Caribbean: Climate Change Implications Science, 7 November 2003, 302, 1024-1027, doi:10.1126/science.1089915, 2003.

Richard, Y., Fauchereau, N., Poccard, I., Rouault, M., and Trzaska, S.: 20th century droughts in southern Africa: spatial and temporal variability, teleconnections with oceanic and atmospheric conditions, Int. J. Climatol., 21, 873-885, doi:10.1002/joc.656, 2001.

Rouault, M. and Richard, Y.; Intensity and spatial extent of droughts in southern Africa, Geophys. Res. Lett., 32, L15702, doi:10.1029/2005GL022436, 2005.

Rojas, O., Vrieling, A., and Rembold, F.: Assessing drought probability for agricultural areas in Africa with coarse resolution remote sensing imagery, Remote Sens. Environ., 115, 343-352, doi:10.1016/j.rse.2010.09.006, 2011.

Rulinda, C. M., Dilo, A., Bijker, W., and Stein, A.: Characterising and quantifying vegetative drought in East Africa using fuzzy modelling and NDVI data, J. Arid Environ., 78, 169-178, 2012.

Sehmi, N. S. and Kundzewicz, Z. W.: Water, drought and desertification in Africa, Sustainability of water resources under increasing uncertainty Proceedings of an international symposium of the Fifth Scientific Assembly of the International Association of Hydrological Sciences IAHS, Rabat, Morocco, 57-65, 1997.

Shanahan, T. M., Overpeck, J. T., Anchukaitis, K. J., Beck, J. W., Cole, J. E., Dettman, D. L., Peck, J. A., Scholz, C. A., and King, J. W.: Atlantic Forcing of Persistent Drought in West Africa, Science, 324, 377-380, doi:10.1126/science.1166352, 2009.

Sheffield, J., Wood, E. F., and Roderick, M. L.: Little change in global drought over the past 60 years, Nature, 491, 435-438, http://www.nature.com/nature/journal/v491/ n7424/abs/nature11575.html\#supplementary-information, 2012.

Sheffield, J., Wood, E. F., Chaney, N., Guan, K., Sadri, S., Yuan, X., Olang, L., Amani, A., Ali, A., Demuth, S., and Ogallo, L.: A Drought Monitoring and Forecasting System for Sub-Sahara African Water Resources and Food Security, B. Am. Meteorol. Soc., 95, 861-882, doi:10.1175/BAMS-D-12-00124.1, 2013.

Smakhtin, V. U. and Schipper, E. L. F.: Droughts: The impact of semantics and perceptions, Water Pol., 10, 131-143, 2008.
Syroka, J. and Nucifora, A.: National drought insuracne for Malawi, Policy Research Working Paper, 5169, The World Bank, available at: http://wwwwds.worldbank.org/servlet/ WDSContentServer/WDSP/IB/2010/01/11/000158349_

20100111161125/Rendered/PDF/WPS5169.pdf (last access: 18 October 2013), 2010.

Tadesse, T., Haile, M., Senay, G., Wardlow, B. D., and Knutson, C. L.: The need for integration of drought monitoring tools for proactive food security management in sub-Saharan Africa, Nat. Resour. Forum, 32, 265-279, 2008.

Tierney, J. E., Smerdon, J. E., Anchukaitis, K. J., and Seager, R,: Multidecadal variability in East African hydroclimate controlled by the Indian Ocean, Nature, 493, 389-392, doi:10.1038/nature11785, 2013.

Tøttrup, A. P., Klaassen, R. H. G., Kristensen, M. W., Strandberg, R., Vardanis, Y., Lindström, Å., Rahbek, C., Alerstam, T., and Thorup, K.: Drought in Africa Caused Delayed Arrival of European Songbirds, Science, 338, p. 1307, doi:10.1126/science.1227548, 2012.

Touchan, R., Anchukaitis, K. J., Meko, D. M., Attalah, S., Baisan, C., and Aloui, A.: Long term context for recent drought in northwestern Africa, Geophys. Res. Lett., 35, L13705, doi:10.1029/2008g1034264, 2008.

Touchan, R., Anchukaitis, K. J., Meko, D. M., Sabir, M., Attalah, S., and Aloui, A.: Spatiotemporal drought variability in northwestern Africa over the last nine centuries, Clim. Dynam., 37, 237-252, 2011.

Trambauer, P., Maskey, S., Werner, M., Pappenberger, F., van Beek, L. P. H., and Uhlenbrook, S.: Identification and simulation of space-time variability of past hydrological drought events in the Limpopo River basin, southern Africa, Hydrol. Earth Syst. Sci., 18, 2925-2942, doi:10.5194/hess-18-2925-2014, 2014.

Traore, Z. and Fontane, D.: Managing Drought Impacts: Case Study of Mali, Africa, J. Water Resour. Plann. Manage., 133, 300-308, doi:10.1061/(ASCE)0733-9496(2007)133:4(300), 2007.

Unganai, L. S. and Kogan, F. N.: Drought Monitoring and Corn Yield Estimation in Southern Africa from AVHRR Data, Remote Sens. Environ., 63, 219-232, doi:10.1016/S00344257(97)00132-6, 1998.

UNISDR (United Nations International Strategy for Disaster Reduction): Living With Risk: A Global Review of Disaster Reduction Initiatives, Geneva, Switzerland: UNISDR, 2004.

UNISDR (United Nations International Strategy for Disaster Reduction): 2010. Declaration of the Second African Ministerial Conference on Disaster Risk Reduction, Nairobi, Kenya, 14-16 April, available at: http://www.unisdr.org/files/ 13655_MinisterialDeclarationinEnglishadop[1].pdf (last access: 12 September 2014), 2010.

Verschuren, D.: Decadal and century-scale climate variability in tropical Africa during the past 2000 years, in: Past climate variability through Europe and Africa, edited by: Battarbee, R. W., Gasse, F., and Stickley, E., Springer, Dordrecht, 139-158, 2004.

Verschuren, D., Laird, K. R., and Cumming, B. F.: Rainfall and drought in equatorial East Africa during the past 1100 years, Nature, 403, 410-414, 2000. 
Vicente-Serrano, S. M., Beguería, S., Gimeno, L., Eklundh, L., Giuliani, G., Weston, D., El Kenawy, A., López-Moreno, J. I., Nieto, R., Ayenew, T., Konte, D., Ardö, J., and Pegram, G. G. S.: Challenges for drought mitigation in Africa: The potential use of geospatial data and drought information systems, Appl. Geograph., 34, 471-486, doi:10.1016/j.apgeog.2012.02.001, 2012.

Vogel, C., Koch, I., and Zyl, K. V.: “A Persistent Truth" - Reflections on Drought Risk Management in Southern Africa, Weather Clim. Soc., 2, 9-22, doi:10.1175/2009WCAS1017.1, 2010.

Williams, A. P. and Funk, C.: A westward extension of the warm pool leads to a westward extension of the Walker circulation, drying eastern Africa, Clim. Dynam., 37, 2417-2435, doi:10.1007/s00382-010-0984-y, 2011.
World Bank, GFDRR: Report on the status of disaster risk reduction in Sub-Saharan Africa, The World Bank, Washington DC, available at: http://www.gfdrr.org/sites/gfdrr.org/files/ publication/AFR.pdf (last access: 18 October 2013), 2010.

Zargar, A., Sadiq, R., Naser, B. and Khan, F. I.: A review of drought indices, Environ. Rev., 19, 333-349, doi:10.1139/a11-013, 2011.

Zeng, N.: Drought in the Sahel, Science, 302, 999-1000, doi:10.1126/science.1090849, 2003.

Zheng, X. and Eltahir, E. A. B.: The response to deforestation and desertification in a model of West African monsoons, Geophys. Res. Lett., 24, 155-158, doi:10.1029/96g103925, 1997. 